\title{
Simultaneous aerosol measurements of unusual aerosol enhancement in the troposphere over Syowa Station, Antarctica
}

\author{
K. Hara ${ }^{1}$, M. Hayashi ${ }^{1}$, M. Yabuki ${ }^{2}$, M. Shiobara ${ }^{3}$, and C. Nishita-Hara ${ }^{1}$ \\ ${ }^{1}$ Department of Earth System Science, Faculty of Science, Fukuoka University, Fukuoka, Japan \\ ${ }^{2}$ Research Institute for Sustainable Humanosphere, Kyoto University, Kyoto, Japan \\ ${ }^{3}$ National Institute of Polar Research, Tokyo, Japan \\ Correspondence to: K. Hara (harakei@ fukuoka-u.ac.jp)
}

Received: 12 September 2013 - Published in Atmos. Chem. Phys. Discuss.: 10 October 2013

Revised: 31 January 2014 - Accepted: 11 March 2014 - Published: 25 April 2014

\begin{abstract}
Unusual aerosol enhancement is often observed at Syowa Station, Antarctica, during winter and spring. Simultaneous aerosol measurements near the surface and in the upper atmosphere were conducted twice using a ground-based optical particle counter, a balloon-borne optical particle counter, and micropulse lidar (MPL) in August and September 2012. During 13-15 August, aerosol enhancement occurred immediately after a storm condition. A high backscatter ratio and high aerosol concentrations were observed from the surface to ca. $2.5 \mathrm{~km}$ over Syowa Station. Clouds appeared occasionally at the top of the aerosol-enhanced layer during the episode. Aerosol enhancement was terminated on 15 August by strong winds from a cyclone's approach. In the second case, on 5-7 September, aerosol number concentrations in $D_{\mathrm{p}}>0.3 \mu \mathrm{m}$ near the surface reached $>10^{4} \mathrm{~L}^{-1}$ at about 15:00 UT (Universal Time) on 5 September despite calm wind conditions, whereas MPL measurement exhibited aerosols were enhanced at about 04:00 UT at 1000-1500 m above Syowa Station. The aerosol enhancement occurred near the surface to ca. $4 \mathrm{~km}$. In both cases, air masses with high aerosol enhancement below $2.5-3 \mathrm{~km}$ were transported mostly from the boundary layer over the sea-ice area. In addition, air masses at 3-4 km in the second case came from the boundary layer over the open-sea area. This air mass history strongly suggests that dispersion of sea-salt particles from the sea-ice surface contributes considerably to aerosol enhancement in the lower free troposphere (about $3 \mathrm{~km}$ ) and that the release of sea-salt particles from the ocean surface engenders high aerosol concentrations in the free troposphere (3-4 km). Continuous MPL measurements indicate that high
\end{abstract}

aerosol enhancement occurred mostly in surface-lower free troposphere $(3 \mathrm{~km})$ during the period July-September.

\section{Introduction}

The Antarctic region, which is isolated from human activity on other continents of low latitudes and midlatitudes, is regarded as the cleanest on the Earth. In general, aerosol number concentrations in the Antarctic coasts are lower than those in other regions (e.g., Ito, 1989, 1993; Weller et al., 2011). Generally speaking, the mean concentration of combustion-origin species such as black carbon (BC) is lower than $10 \mathrm{ng} \mathrm{m}^{-3}$ at the Antarctic coasts and in inland areas (Bodhaine, 1995; Wolff and Cachier, 1998; Pereira et al., 2006; Weller et al., 2013). The BC levels suggest that the Antarctic region remains in the cleanest of conditions, although previous investigations have pointed out that $\mathrm{BC}$ is supplied mostly by long-range transport from biomass burning in South America, Africa, and Australia (van der Werf et al., 2006, 2008; Fiebig et al., 2009; Hara et al., 2010). Nevertheless, haze phenomena have occurred at Syowa Station, Antarctica, because of remarkably high aerosol concentrations during winter and spring in 2004-2006 (Hara et al., 2010).

The following basic physical and chemical properties of the Antarctic haze (aerosol enhancement) were obtained from ground-based aerosol measurements at Syowa Station in 2004-2006 (Hara et al., 2010, 2011a) under the following conditions. (1) Visibility dropped to $<10 \mathrm{~km}$ in spite of calm wind conditions and a lack of drifting snow. 
(2) Haze conditions often occurred immediately after storm conditions attributable to a cyclone's approach. (3) Aerosol number concentrations near the surface increased in all size ranges (10nm-supermicrometer). (4) Concentrations of combustion-origin aerosol species such as $\mathrm{BC}, \mathrm{NO}_{3}^{-}$, and organic acids increased. (5) Sea salts were the dominant aerosol species in the Antarctic haze. (6) Sea-salt particles emitted from sea-ice surface were mixed in all size ranges $\left(D_{\mathrm{p}}<0.2,0.2-2\right.$, and $\left.>2 \mu \mathrm{m}\right)$. (6) Surface $\mathrm{O}_{3}$ concentrations dropped after polar sunrise. Because of restrictions in logistics under severe conditions, in situ aerosol measurements in the upper boundary layer-free troposphere in Antarctic regions have limited our knowledge of the vertical distributions of aerosols under Antarctic haze (aerosol enhancement) conditions. Airplanes, tethered balloons, and launched balloons have been applied in several investigations of aerosol measurements in the upper boundary layer-free troposphere over Syowa Station (Hara et al., 2011b, and references therein). Airplane-borne aerosol measurements conducted by Yamanouchi et al. (1999) revealed high aerosol concentrations from the surface to approximately $2300 \mathrm{~m}$ above sea level (a.s.l.) over Syowa Station on 30 August 1997 immediately after the storm conditions. Balloon-borne aerosol measurements taken using an optical particle counter (OPC) on 18 June 2004 also exhibited aerosol enhancement in the surface-approximately $3000 \mathrm{~m}$ a.s.l. over Syowa Station (Hara et al., 2011b, and references therein). Tethered balloon-borne aerosol measurements over Syowa Station in 2005 revealed that aerosols were enhanced in the boundary layer and lower free troposphere, and that sea-salt particles were dominant under the aerosol-enhanced conditions (Hara et al., 2011b, 2013). These measurements provided important knowledge, especially knowledge related to the thickness of the aerosol-enhanced layer and aerosol constituents, but the time series of vertical distributions of aerosol properties under the Antarctic haze (aerosol enhancement) conditions have never been reported. Knowledge about seasonal and vertical features of Antarctic haze is essential to discuss and estimate the plausible impact to atmospheric chemistry related to sea-salt and halogen cycles in atmosphere, radiation budgets, and climate change in the Antarctic regions. To elucidate the seasonal and vertical structure of Antarctic haze (aerosol enhancement), this study combines ground-based aerosol measurements, remote sensing, and in situ aerosol measurements in the upper boundary layer-free troposphere. This investigation aimed to understand vertical structures and seasonal features of Antarctic haze (aerosol enhancement) based on the simultaneous aerosol measurements conducted over Syowa Station, Antarctica.

\section{Aerosol measurements and data analysis}

\subsection{Continuous aerosol measurements near the surface}

Syowa Station $\left(69.00^{\circ} \mathrm{S}, 39.59^{\circ} \mathrm{E}\right)$ is located on East Ongul Island in Lützow-Holm Bay, ca. $4 \mathrm{~km}$ from the Prince Olav coast of Antarctica. Seasonal features of sea-ice extent off Syowa Station show a minimum around February and a maximum in September-October (e.g., Comiso, 2010). The seaice margin on the $40^{\circ} \mathrm{E}$ line is located at approximately $58-60^{\circ} \mathrm{S}$ in September-October. It is approximately $100 \mathrm{~km}$ from Syowa Station during the summer and $1000 \mathrm{~km}$ distant during winter and spring.

Ground-based aerosol measurements were conducted at a "clean air observatory" built on the windward side, considering prevailing winds, from the main area of the station. Ambient air was taken at an air inlet ca. $5 \mathrm{~m}$ above the snow surface. Details of the clean air observatory were described by Osada et al. (2006) and by Hara et al. (2010). Number concentrations and size distributions of aerosol particles were monitored using OPC (TD100; Sigma Tech.), the measurable size ranges of which were $D_{\mathrm{p}}$ (diameter) $>0.3,>0.5,>1.0$, $>2.0,>3.0$, and $>5.0 \mu \mathrm{m}$. The OPC was calibrated using polystyrene latex spheres with a refractive index of $1.59-0 \mathrm{i}$. Aerosol number concentrations were measured every minute (counting time for $58 \mathrm{~s}$ ) at a flow rate of $1 \mathrm{~L} \mathrm{~min}^{-1}$. OPC and CPC were operated under room temperature conditions (ca. $20^{\circ} \mathrm{C}$ ). The number concentrations of dry aerosol particles were monitored in this study. Although the observatory was located on the windward side, local contamination occurs depending on wind conditions. Aerosol data were filtered to remove locally contaminated data using wind speed, wind direction, and the number concentration of condensation nuclei $(\mathrm{CN})$ in accordance with criteria described by Hara et al. (2010, 2011a). Meteorological data were measured by the Japanese Meteorological Agency at the meteorological observatory located in the main area of the station.

\subsection{MPL system and analysis}

The vertical distributions of aerosols and clouds were measured continuously using micropulse lidar (MPL; Science \& Engineering Service Inc.) at the Atmospheric Observatory in the main area of the station. The MPL is a singlechannel elastic backscatter lidar with $523 \mathrm{~nm}$ wavelength. A diode-pumped Nd:YLF (neodymium-doped yttrium lithium fluoride) laser is vertically transmitted into the atmosphere with a repetition rate of $2500 \mathrm{~Hz}$. The backscattered light from atmospheric gases and aerosol particles was received with a Schmidt-Cassegrain telescope ( $20 \mathrm{~cm}$ diameter). The field of view of the receiver is $100 \times 10^{-6}$ radians. The MPL can receive a return signal from a $60 \mathrm{~km}$ range with range resolution of $30 \mathrm{~m}$. Data were acquired in the $1 \mathrm{~min}$ pulseintegration mode. Details of the MPL system installed at 
Syowa Station were reported by Shiobara et al. (2003) and Shibata et al. (2003).

Campbell et al. (2002) outlined correction procedures for the MPL raw signal by accounting for ambient background light and instrument-specific terms. Lidar signals in the near range are affected by signal losses caused by the incomplete overlap of the laser beam and the receiver field of view. Overlap is typically resolved in experimental cases using the horizontal lidar measurement with a spatially homogeneous aerosol distribution in the target layer (Campbell et al., 2002). However, the observatory location was unsuitable for observing the horizontal sightline with no obscuration. We estimated the overlap from vertical profiles when the aerosol loading was low (i.e., the target layer is assumed to contain no aerosols). We chose a time when the backscatter through the layer was roughly assumed to be a Rayleigh signal with range by referring to the molecular backscatter intensity derived from the mean temperature and pressure profiles observed by the GPS sonde during the same season. In Antarctic regions, the aerosol optical depth (AOD) under background conditions is extremely low (Tomasi et al., 2012). The values of AOD at a wavelength of $500 \mathrm{~nm}$ under Antarctic background conditions are at least several times smaller than those of the Rayleigh optical depth. Therefore, this assumption does not markedly affect the derived aerosol profiles. The overlap function was estimated by fitting between the averaged lidar-returned signal under clear air conditions and the theoretical Rayleigh profile.

The aerosol backscatter ratio $\left(R=\left(\beta_{\mathrm{a}}+\beta_{\mathrm{m}}\right) / \beta_{\mathrm{m}}\right)$ from the lidar signal was estimated using the backward inversion method (Fernald, 1984), where $\beta_{\mathrm{a}}$ and $\beta_{\mathrm{m}}$ respectively denote the backscatter coefficients of aerosol and molecules. This method assumes a linear relation between the aerosol extinction coefficient $\alpha_{\mathrm{a}}$ and $\beta_{\mathrm{a}}$ in the form of the lidar ratio $S_{1}=\alpha_{\mathrm{a}} / \beta_{\mathrm{a}}$. However, the lidar ratio depends on the size distribution and the refractive index of the aerosol particles as well as on the lidar wavelength. For example, the values of $S_{1}$ vary between 20 and $70 \mathrm{sr}$ for six aerosol types (dust, polluted dust, clean marine, clean continental, pollution, and biomass burning), as defined in the aerosol classification algorithms and the lidar ratio selection schemes for the CloudAerosol Lidar and Infrared Pathfinder Satellite Observations (CALIPSO) aerosol products (Omar et al., 2009). However, the values of $S_{1}$ under the Antarctic haze condition, which are emphasized in this study, cannot be defined clearly because we have insufficient information about the aerosol optical properties in this phenomenon. Therefore, we use a fixed value of $S_{1}=30 \mathrm{sr}$, which is close to the mean of the values for clean continental air $(35 \mathrm{sr})$ and clean marine air $(20 \mathrm{sr})$ at a wavelength of $532 \mathrm{~nm}$, as reported by Omar et al. (2009). Vertical profiles of aerosol backscatter ratio were calculated for the $3 \mathrm{~min}$ averages of lidar data.

\subsection{Measurements with balloon-borne optical particle counter}

Vertical features of aerosol number concentrations and size distributions were measured using balloon-borne OPC (Yamanashi Gijutu Kobou Co. Ltd.). The balloon-borne OPC was calibrated using polystyrene latex spheres with a refractive index of 1.59-0i. For balloon-borne measurements, the measurable size range of the balloon-borne OPC was set to $D_{\mathrm{p}}>0.3,>0.5,>0.8,>1.2,>2.0,>3.4,>5.0$, and $>7.0 \mu \mathrm{m}$, which correspond to spherical particle diameters with a refractive index of $1.40-0 \mathrm{i}$, and which were estimated using Mie scattering theory. Threshold sizes with refractive index 1.59-0i corresponded to $D_{\mathrm{p}}>0.26,>0.41,>0.65,>1.4$, $>2.3,>2.9,>4.8$, and $>6.5 \mu \mathrm{m}$. Details of the balloon-borne OPC were reported by Iwasaki et al. (2007) and Shibata et al. (2012). The balloon-borne OPC was launched simultaneously with GPS sonde (RS03G; Meisei Electric Co. Ltd.), which transmits aerosol number concentration data to the ground in addition to meteorological data and GPS data. Balloon-borne OPCs were launched from Syowa Station under aerosol-enhanced conditions near the surface at 06:55 UT on 14 August 2012 and at 14:33 UT on 6 September 2012.

\section{Results and discussion}

\subsection{Aerosol enhancement on 13-15 August 2012}

\subsubsection{Aerosol features near the surface}

Figure 1 depicts variations of aerosol number concentrations and mass concentrations near the surface at Syowa Station during the period 13-16 August 2012. Because of strong winds under storm conditions, high aerosol number concentrations were observed on 13 August 2012. For instance, aerosol number concentrations in $D_{\mathrm{p}}>0.3 \mu \mathrm{m}$ and $D_{\mathrm{p}}>2.0 \mu \mathrm{m}$ changed from ca. $4.3 \times 10^{4}$ to $1.1 \times 10^{4} \mathrm{~L}^{-1}$, and from 580 to $212 \mathrm{~L}^{-1}$, respectively, at around 19:15 UT on 13 August when the wind speed decreased suddenly to less than $5 \mathrm{~m} \mathrm{~s}^{-1}$. In spite of weak wind conditions $\left(<5 \mathrm{~m} \mathrm{~s}^{-1}\right)$, the aerosol number concentrations in $D_{\mathrm{p}}>0.3 \mu \mathrm{m}$ and $D_{\mathrm{p}}>2.0 \mu \mathrm{m}$ increased markedly to greater than $5 \times 10^{4}$ and $600 \mathrm{~L}^{-1}$ respectively, at approximately 22:41 UT on 13 August. Median aerosol number concentrations in August 2012 under background conditions with wind speed of less than $5 \mathrm{~m} \mathrm{~s}^{-1}$ were $2820 \mathrm{~L}^{-1}$ in $D_{\mathrm{p}}>0.3 \mu \mathrm{m}$ and $35 \mathrm{~L}^{-1}$ in $D_{\mathrm{p}}>2.0 \mu \mathrm{m}$. These concentration levels were consistent with previous investigations by Osada et al. (2010) and Hara et al. (2010, 2011b). Indeed, aerosol number concentrations before the storm conditions on 13 August were approximately 1980 and $4 \mathrm{~L}^{-1}$ in $D_{\mathrm{p}}>0.3$ and $D_{\mathrm{p}}>2.0 \mu \mathrm{m}$, respectively. Although drifting snow and fog can enhance the aerosol number concentrations, drifting snow and fog were not observed under conditions with calm winds and relative humidity lower than $83 \%$. Consequently, the high 
number concentrations might be identified as the occurrence of aerosol enhancement (Antarctic haze). As reported also by Hara et al. (2010), aerosol enhanced (Antarctic haze) conditions appeared immediately after storm conditions. Strong winds by the next cyclone approach engendered drifting snow and increased aerosol concentrations at 06:58 UT on 16 August before a drop of the aerosol number concentrations at the end of aerosol enhancement. The duration of the aerosol enhancement was estimated as $56.3 \mathrm{~h}$ in this case. Using the duration time and mean surface wind speeds, the horizontal scales of the Antarctic haze events were estimated at approximately $405 \mathrm{~km}$.

Here, we attempt to estimate the mass concentrations using aerosol number concentrations, assuming spherical shape and density of aerosol particles. The density corresponded to the density of sulfates (ca. $1.8 \mathrm{~g} \mathrm{~cm}^{-3}$ ) and $\mathrm{NaCl}$ $\left(2.2 \mathrm{~g} \mathrm{~cm}^{-3}\right)$. According to Hara et al. (2010, 2011a, 2013), sea-salt particles were dominant under the Antarctic haze conditions. In addition, aerosol number concentrations were observed under dry conditions at the clean air observatory. Therefore, we used the density of $2.0 \mathrm{~g} \mathrm{~cm}^{-3}$ to estimate the mass concentration in this study. The number concentrations of aerosol particles smaller than $0.3 \mu \mathrm{m}$ were not included in the estimation. Therefore, the estimated mass concentrations can be slightly underestimated. During the aerosol enhancement on 14-16 August, mass concentration near surface reached $18.2 \mu \mathrm{g} \mathrm{m}^{-3}$. With the decrease of the number concentrations, mass concentrations decreased gradually to $4.4 \mu \mathrm{g} \mathrm{m}^{-3}$. The mass concentrations agreed well with sea-salt concentrations in most cases described in Hara et al. (2010). The mass concentrations in the heaviest Antarctic haze in August 2005, however, were 17-25 $\mu \mathrm{g} \mathrm{m}^{-3}$ (Hara et al., 2010). Therefore, comparison with data from a previous investigation by Hara et al. (2010) revealed that the scale of the aerosol enhancement in Fig. 1 might be intermediate.

As depicted in Fig. 1, the number concentrations increased remarkably in all size ranges during aerosol enhancement. After 10:08 UT on 14 August, the number concentrations decreased gradually. Particularly, the number concentrations in larger sizes decreased significantly (e.g., approximately two order decrease in $\left.D_{\mathrm{p}}>3.0 \mu \mathrm{m}\right)$. In general, variations of aerosol number concentrations and size distribution are controlled by formation, emission, coagulation, dry deposition, wet deposition, and size change by hygroscopicity. We specifically examine the aerosol number concentrations and size distribution in fine-coarse mode. Therefore, the contribution of new particle formation and coagulation can be negligible. Because of calm winds (mean $1.7 \mathrm{~m} \mathrm{~s}^{-1}$ ), local aerosol emissions from snow and sea-ice surfaces were probably not significant during the period 14-16 August. In addition, the relative humidity changed gradually from 80 to $70 \%$. Considering that the aerosol number concentrations decreased even under the extremely small change of relative humidity, the change of relative humidity cannot wholly account for the gradual decrease of the aerosol number con-
Table 1. Fitting parameters in the exponential decay for aerosol number concentrations of each size from 09:45 UT on 14 August $(\mathrm{DOY}=226.407)$ until 06:25 UT on 16 August (DOY $=228.268)$.

\begin{tabular}{lccc}
\hline Size range & $\mathrm{a}^{*}$ & $\mathrm{~b}^{*}$ & $R^{2}$ \\
\hline$D_{\mathrm{p}}>3 \mu \mathrm{m}$ & 7.160 & $2.537 \times 10^{-5}$ & 0.8543 \\
$D_{\mathrm{p}}>2 \mu \mathrm{m}$ & $3.439 \times 10^{2}$ & $1.043 \times 10^{-5}$ & 0.8518 \\
$D_{\mathrm{p}}>1 \mu \mathrm{m}$ & $1.397 \times 10^{3}$ & $9.089 \times 10^{-6}$ & 0.8496 \\
$D_{\mathrm{p}}>0.5 \mu \mathrm{m}$ & $9.563 \times 10^{3}$ & $7.133 \times 10^{-6}$ & 0.8910 \\
$D_{\mathrm{p}}>0.3 \mu \mathrm{m}$ & $3.337 \times 10^{4}$ & $5.468 \times 10^{-6}$ & 0.9141 \\
\hline
\end{tabular}

* Exponential decay function is " $y=a e^{-b x}$ ".

centrations. Consequently, it is expected that a remarkable decrease in coarse particles is associated with larger dry deposition velocity in coarse mode. To verify the contribution of dry deposition to the features of aerosol number density from 09:45 UT on 14 August until 06:25 UT on 16 August, we attempt to roughly estimate features of the aerosol number concentrations by dry deposition. The relation between aerosol number concentrations and deposition velocity can be given as

$\mathrm{d} N=-\frac{V_{\mathrm{dep}}}{H} N \mathrm{~d} t$,

where $N, V_{\text {dep }}$, and $H$ respectively denote the aerosol number concentration, deposition velocity, and height of the mixing layer. Then, Eq. (1) can be modified to

$N=N_{0} e^{-\frac{V_{\text {dep }}}{H} t}$,

where $N_{0}$ denotes the initial number concentration. Therefore, variations of the aerosol number concentrations of each size range were fitted by an exponential decay function in this study. The fitting parameters for each size range are presented in Table 1. Vertical profiles of temperature, relative humidity, and aerosol number concentrations show that the height of the boundary layer was approximately $530 \mathrm{~m}$ on 14 August 2012 (details are described Sect. 3.1.2). Assuming that the height of the boundary layer is constant, $V_{\mathrm{dep}}$ can be estimated as $1.26 \mathrm{~cm} \mathrm{~s}^{-1}$ in $D_{\mathrm{p}}>3 \mu \mathrm{m}, 0.55 \mathrm{~cm} \mathrm{~s}^{-1}$ in $D_{\mathrm{p}}>2 \mu \mathrm{m}, 0.48 \mathrm{~cm} \mathrm{~s}^{-1}$ in $D_{\mathrm{p}}>1 \mu \mathrm{m}, 0.38 \mathrm{~cm} \mathrm{~s}^{-1}$ in $D_{\mathrm{p}}>0.5 \mu \mathrm{m}$, and $0.29 \mathrm{~cm} \mathrm{~s}^{-1}$ in $D_{\mathrm{p}}>0.3 \mu \mathrm{m}$. The estimated values were well consistent with the dry deposition velocity (Grönlund et al., 2002; Seinfeld and Pandis, 2006). Therefore, the gradual decrease of aerosol number concentrations might result mostly from the dry deposition of aerosol particles during transport.

\subsubsection{Aerosol features in boundary layer-free troposphere}

Because of storm conditions and snow deposition on the window of the atmospheric observatory for MPL measurement, 


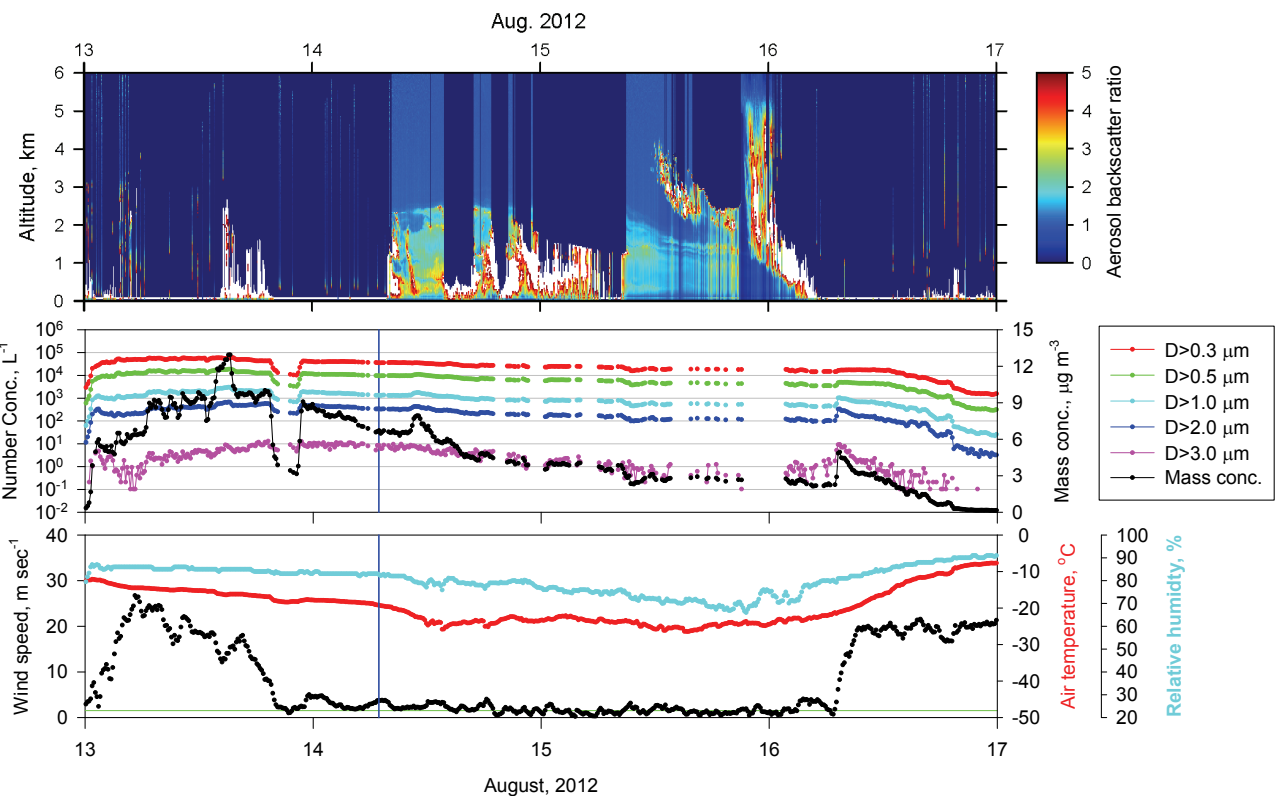

Fig. 1. Short-term variation of aerosol backscatter ratio, aerosol number concentration, mass concentration, wind speed, air temperature, and relative humidity near the surface on 13-16 August 2012 at Syowa Station, Antarctica.

vertical distributions of aerosol backscatter ratio were not obtained during the early stage of the aerosol enhancement (before 09:00 UT on 14 August), as shown in Fig. 1. Moreover, the cloud appearance and precipitation prevented identification of vertical structure of the aerosol enhancement from 14:00 UT on 14 August until 09:00 UT on 15 August. The MPL measurements during cloud-free periods over MPL on 14 and 15 August exhibited that an aerosol backscatter ratio close to 2 was observed at altitudes lower than ca. $2500 \mathrm{~m}$ on 14-15 August 2012. During the period 11:00-13:00 UT on 14 August, a cloud-free period, the aerosol backscatter ratio was $2-3$ in the boundary layer and lower free troposphere $(<1500 \mathrm{~m})$; it was $1.5-2$ in the lower free troposphere $(1500-2500 \mathrm{~m})$. Although aerosols were enhanced at altitudes $<2500 \mathrm{~m}$ on 14 August, a thin aerosol layer with lower backscatter ratio was clearly identified at ca. 500 and $2000 \mathrm{~m}$. After the cloud disappearance at around 09:00 UT on $15 \mathrm{Au}-$ gust, the aerosol-enhanced layer remained in the lower troposphere over Syowa Station. The aerosol backscatter ratio was $1.5-2.3$ at altitudes lower than $2 \mathrm{~km}$ on 15 August. Furthermore, the height of the top of aerosol-enhanced layer descended gradually to $<1.5 \mathrm{~km}$ at $21: 25$ UT on 15 August. Aerosol enhancement occurred from the surface to the lower free troposphere (ca. $2500 \mathrm{~m}$ ) in this case. This thickness was similar to the thickness observed in earlier investigations by Yamanouchi et al. (1999) and Hara et al. (2011b).

Figure 2 depicts the vertical distributions of potential temperature, relative humidity, aerosol number concentrations, mass concentrations, and the backscatter ratio over Syowa Station on 14 August. Unfortunately, MPL data were not obtained during balloon-borne OPC measurements in this case because of snow deposition on the MPL window. The vertical profile of potential temperature shows that the gradient of potential temperature changed at approximately 500, 970,1600 , and $2260 \mathrm{~m}$. The temperature difference at $2200 \mathrm{~m}$ was greater than $5 \mathrm{~K}$. These altitudes correspond to the vertically layered structure of aerosol number concentrations and mass concentrations. The vertical features of potential temperature and aerosol number concentrations imply that the boundary layer height was approximately $500 \mathrm{~m}$ on 14 April 2012. For instance, the aerosol number concentrations of $D_{\mathrm{p}}>0.26 \mu \mathrm{m}$ in each layer were approximately $6.6 \times 10^{4}$, $1.4 \times 10^{4}, 3.0 \times 10^{4}$, and $1.4 \times 10^{4} \mathrm{~L}^{-1}$, respectively. In contrast to vertical features of aerosol number concentrations in fine mode, the number concentrations in $D_{\mathrm{p}}>2.9,4.8$, and $6.5 \mu \mathrm{m}$ increased gradually to 353,252 , and $171 \mathrm{~L}^{-1}$, respectively, in 1100-2130 m. Particularly, the aerosol number concentrations increased in all size ranges in 2100-2200 m under conditions with higher relative humidity, so that a cloud layer appeared at this altitude. The aerosol number concentrations were enhanced, only in coarse mode, at $1600-2100 \mathrm{~m}$. Therefore, aerosol particles might be activated to cloud particles at this altitude under high relative-humidity conditions. Aerosol-enhanced conditions above the cloud layer were observed up to $2500 \mathrm{~m}$.

Mass concentrations higher than $10 \mu \mathrm{g} \mathrm{m}^{-3}$ were obtained from near surface to ca. $1600 \mathrm{~m}$, although mass concentrations decreased to ca. $5 \mu \mathrm{g} \mathrm{m}^{-3}$ at $900-1000 \mathrm{~m}$. Although the highest mass concentrations (ca. $1087 \mu \mathrm{g} \mathrm{m}^{-3}$ ) were observed at $2200 \mathrm{~m}$, the altitudes corresponded to cloud layer. The layered structure was observed in the vertical features of aerosol backscatter ratio at 10:00-13:00 UT on 14 August, 


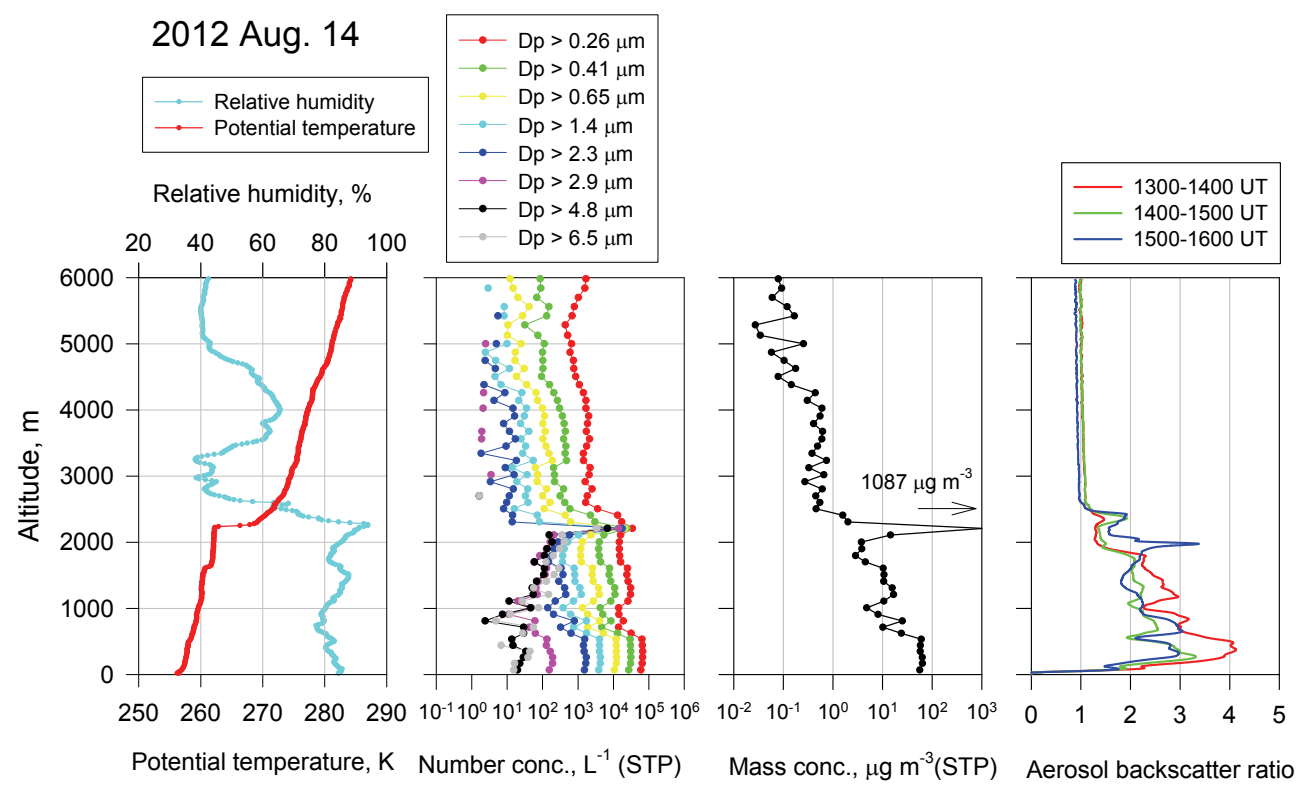

Fig. 2. Vertical variations of potential temperature, relative humidity, aerosol number concentration, mass concentration, and backscatter ratio over Syowa Station on 14 August 2012. Vertical blue line represents the time of aerosol sonde launch.

although measurements obtained from balloon-borne OPC and MPL were not conducted simultaneously. These altitudes corresponded roughly to lower aerosol number concentrations in the balloon-borne OPC measurements. Consequently, the layered structure might persist for at least several hours. Moreover, mass concentrations higher than $50 \mu \mathrm{g} \mathrm{m}^{-3}$ were observed at altitudes below ca. $600 \mathrm{~m}$. Mass concentrations above the cloud layer were approximately $0.5 \mu \mathrm{g} \mathrm{m}^{-3}$ at 2500-4200 m. Furthermore, mass concentrations decreased occasionally to lower than $0.1 \mu \mathrm{g} \mathrm{m}^{-3}$ at $4400-6000 \mathrm{~m}$.

\subsubsection{Air mass history of the aerosol-enhanced layer}

As shown in weather charts in the Supplement, two cyclones approached Syowa Station on 13 August, when a storm occurred. Although the closest cyclone was located around $30^{\circ} \mathrm{E}, 68^{\circ} \mathrm{S}$ on 13 August, the cyclone weakened suddenly on 14 August. The sudden decline of the cyclone before occurrence of Antarctic haze was observed also in cases of Antarctic haze in 2004-2006 at Syowa Station (Hara et al., 2010). On 15 August, Syowa Station was located in the ridge of an anticyclone. Then, the next cyclone approached Syowa Station from the west after the afternoon of $15 \mathrm{Au}-$ gust. As shown in Fig. 1, the next cyclone approach caused a storm condition on 15 August at Syowa Station. To elucidate the air mass history of the aerosol-enhanced layer, the 5day backward trajectory was computed from every $200 \mathrm{~m}$ at 200-4000 m over Syowa Station using vertical motion mode in the NOAA-HYSPLIT (Hybrid Single-Particle Lagrangian Integrated Trajectory) model with NCEP (National Centers for Environmental Prediction) reanalysis data (Draxler and Rolph, 2013).
Figure 3 presents examples of the 5-day backward trajectory at 03:00 UT on 14 August 2012. Air masses in the aerosol-enhanced layer had traveled over the sea-ice area for the previous 5 days. Air masses passed at altitudes mostly lower than $1500 \mathrm{~m}$ over sea-ice regions. Particularly, the backward trajectory from 1000-1500 m over Syowa Station showed that air masses were transported from the boundary layer $(<500 \mathrm{~m})$ over a sea-ice area. Air masses in the aerosolenhanced layer originated mostly from the boundary layerlower free troposphere $(<1500 \mathrm{~m})$ over the sea-ice area. By contrast, air masses above the aerosol-enhanced layer were distributed higher than $2000 \mathrm{~m}$ over the sea-ice area. Considering that sea-salt particles were dominant under Antarctic haze conditions and storm conditions in our previous studies (Hara et al., 2010, 2011a), the difference strongly suggests that the aerosol-enhanced layer in the lower troposphere was associated with a release of aerosol particles from the seaice surface. Strong winds attributable to a cyclone approach might cause a considerable dispersion of sea-salt particles from the sea-ice surface. Then, a sudden decline of a cyclone can maintain conditions with marked dispersion of seasalt particles (i.e., aerosol enhancement) in the surface-lower free troposphere.

As described above, the top of the aerosol-enhanced layer descended gradually on 15 August, when Syowa Station was located in a high-pressure ridge (shown in the Supplement). The backward trajectory indicated that air masses above the aerosol-enhanced layer on 15 August derived from the free troposphere $(>3500 \mathrm{~m})$ over the Weddell Sea and Antarctic Peninsula (Fig. 3). In contrast, air masses in the aerosol-enhanced layer on 15 August traveled in the lower 

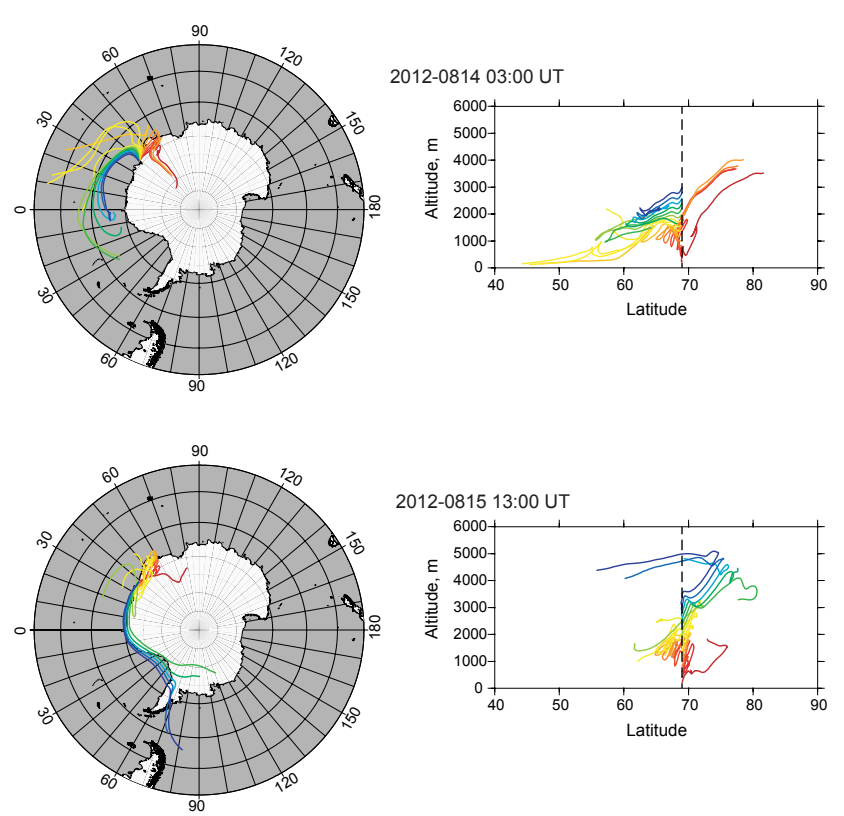

Fig. 3. Examples of 5-day backward trajectory at 03:00 UT on 14 August and at 13:00 UT on 15 August. Dashed line represents the latitude of Syowa Station $\left(69^{\circ} \mathrm{S}\right)$. Trajectories are color coded to correspond to initial height over Syowa Station.

troposphere $(<2000 \mathrm{~m})$ over sea ice and the Antarctic coast around Syowa Station. Therefore, a gradual descent of the top of the layer might result from (1) the location of a highpressure ridge and (2) transport of clean air in the free troposphere over Syowa Station.

\subsection{Aerosol enhancement on 6 September 2012}

\subsubsection{Aerosol features near the surface}

Figure 4 depicts variations of aerosol number concentrations and mass concentrations near the surface at Syowa Station during the period 4-7 September 2012. Although aerosol enhancements in the cases of August 2012 (Sect. 3.1) and previous studies (Hara et al., 2010) occurred immediately after the storm conditions, the wind speed near the surface was $<5 \mathrm{~m} \mathrm{~s}^{-1}$ before the aerosol enhancement in this case. This difference is useful to elucidate the origin and transport processes of Antarctic haze and the aerosol-enhanced layer. In addition, the aerosol number concentrations dropped before aerosol enhancement because of slight precipitation near the surface on 5 September. Mass concentrations were decreased to $0.02 \mu \mathrm{g} \mathrm{m}^{-3}$, which corresponded to the mass concentration in the free troposphere, as presented in Fig. 2. Then, the aerosol number concentrations in $D_{\mathrm{p}}>0.3 \mu \mathrm{m}$ increased gradually and exceeded $10^{4} \mathrm{~L}^{-1}$ at 15:04 UT on 5 September, when the relative humidity and air temperature respectively started to decrease and increase simultaneously. Those simultaneous changes suggest that a "frontlike" structure passed over Syowa Station. Aerosol number concentrations in $D_{\mathrm{p}}>0.3 \mu \mathrm{m}$ reached $3.7 \times 10^{4} \mathrm{~L}^{-1}$ during aerosol enhancement, although the number concentrations in $D_{\mathrm{p}}>2.0$ and $3.0 \mu \mathrm{m}$ were, respectively, 20-170 (mean, $106 \mathrm{~L}^{-1}$ ) and $<2 \mathrm{~L}^{-1}$ (mean, $0.4 \mathrm{~L}^{-1}$ ). Although the number concentrations of $D_{\mathrm{p}}>0.3 \mu \mathrm{m}$ resembled those on 14-16 August, the number concentrations in $D_{\mathrm{p}}>2.0$ and $3.0 \mu \mathrm{m}$ were several factors or one order smaller than those on 14-16 August (Fig. 1). Because of the lower number concentrations in coarse mode, the mass concentrations during aerosol enhancement on 5-7 September were 2-10 $\mu \mathrm{g} \mathrm{m}^{-3}$, which were lower than those of the case in August. Aerosol enhancement $\left(10^{4} \mathrm{~L}^{-1}\right.$ in $\left.D_{\mathrm{p}}>0.3 \mu \mathrm{m}\right)$ remained near the surface until 08:00 UT on 7 September. Unlike the sudden decrease of aerosol number concentrations in the cases described in Hara et al. (2010), the number concentrations in $D_{\mathrm{p}}>0.3 \mu \mathrm{m}$ decreased gradually to $<10^{4} \mathrm{~L}^{-1}$. The duration of the aerosol enhancement was identified as $40.9 \mathrm{~h}$. The horizontal scale of the aerosol enhancement was estimated approximately to $255 \mathrm{~km}$ using mean surface wind speeds.

\subsubsection{Aerosol features in the boundary layer-free troposphere}

As portrayed in Fig. 4, the aerosol-enhanced layer was not observed before 13:00 UT on 4 September. After 14:00 UT on 4 September, the aerosol backscatter ratio increased slightly by 1.4 in the boundary layer and in the lower free troposphere $(<4 \mathrm{~km})$. Remarkable aerosol enhancement started below $1 \mathrm{~km}$ at 01:00 UT on 5 September. The top altitude of the aerosol-enhanced layer rose gradually to ca. $2.7 \mathrm{~km}$ on 5 September. Particularly, the aerosol backscatter ratio exceeded 4 at 1-1.8 km during the period 12:00-13:30 UT on 5 September. Remarkably, aerosol enhancement continued on 6 September. The top of the aerosol-enhanced layer was identified at ca. $2.7 \mathrm{~km}$ on 6 September. Moreover, the aerosolenhanced layer with aerosol backscatter ratio larger than 2 was expanded up to ca. $4 \mathrm{~km}$ until 08:00 UT on 6 September. After 03:00 UT on 6 September, the aerosol backscatter ratio decreased to less than 2 below $1 \mathrm{~km}$. Considering that the top of the boundary layer was usually $<1000 \mathrm{~m}$ during winter through spring (this study, and Hara et al., 2011b), Antarctic haze (aerosol enhanced condition) might be distributed not only near the surface and boundary layer, but also in the lower free troposphere over Syowa Station. Aerosol enhancement at altitudes higher than $2 \mathrm{~km}$ was terminated approximately at 13:00 UT on 6 September, although the aerosol-enhanced layer thickness became markedly less at altitudes lower than $2 \mathrm{~km}$. The aerosol backscatter ratio decreased gradually in the lower free troposphere. Then, aerosol enhancement above $1 \mathrm{~km}$ remained until 22:00 UT on 6 September.

Figure 5 depicts vertical distributions of potential temperature, relative humidity, aerosol number concentrations, mass concentrations, and aerosol backscatter ratio over Syowa Station on 6 September. Balloon-borne OPC measurements 


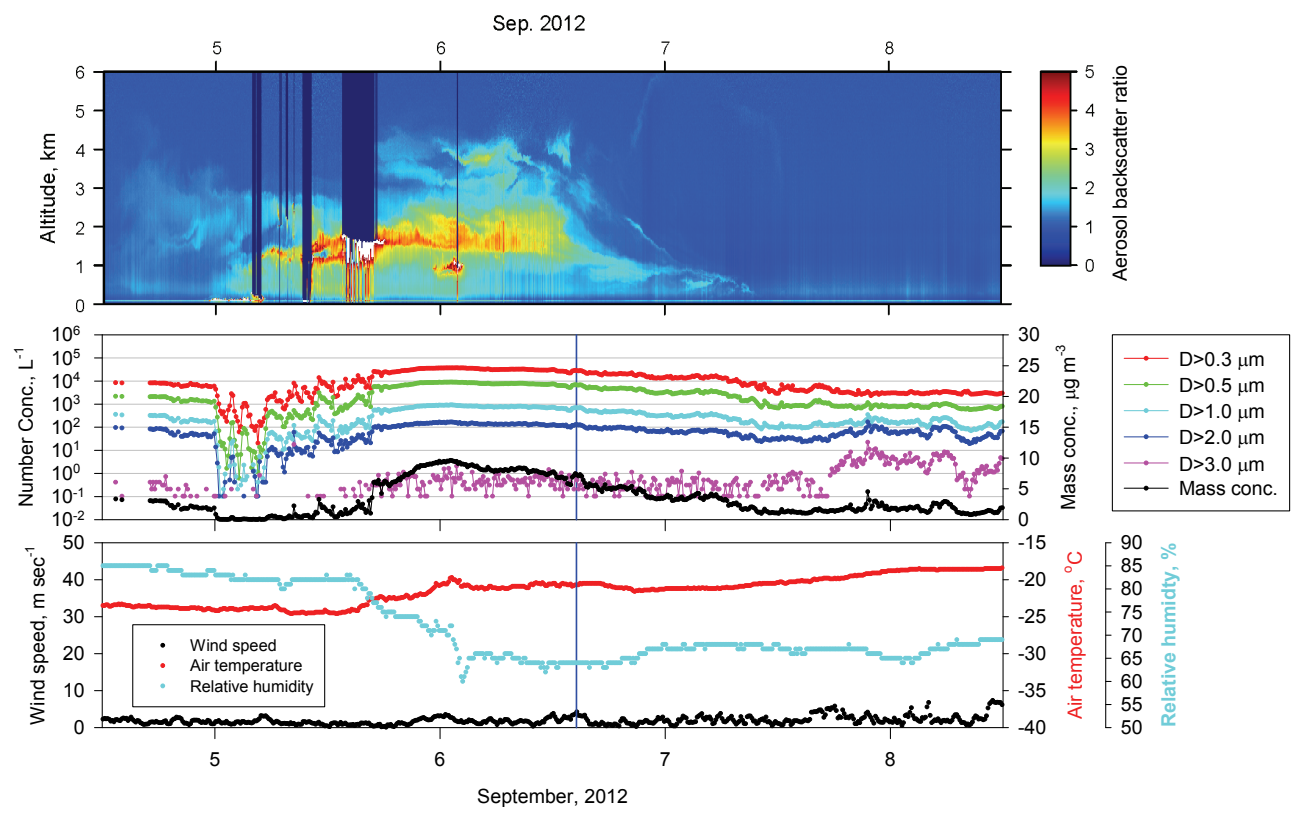

Fig. 4. Short-term variations of the aerosol backscatter ratio, aerosol number concentration, mass concentration, wind speed, air temperature, and relative humidity near the surface on 4-7 September 2012 at Syowa Station, Antarctica. Vertical blue line represents the time of aerosol sonde launch.

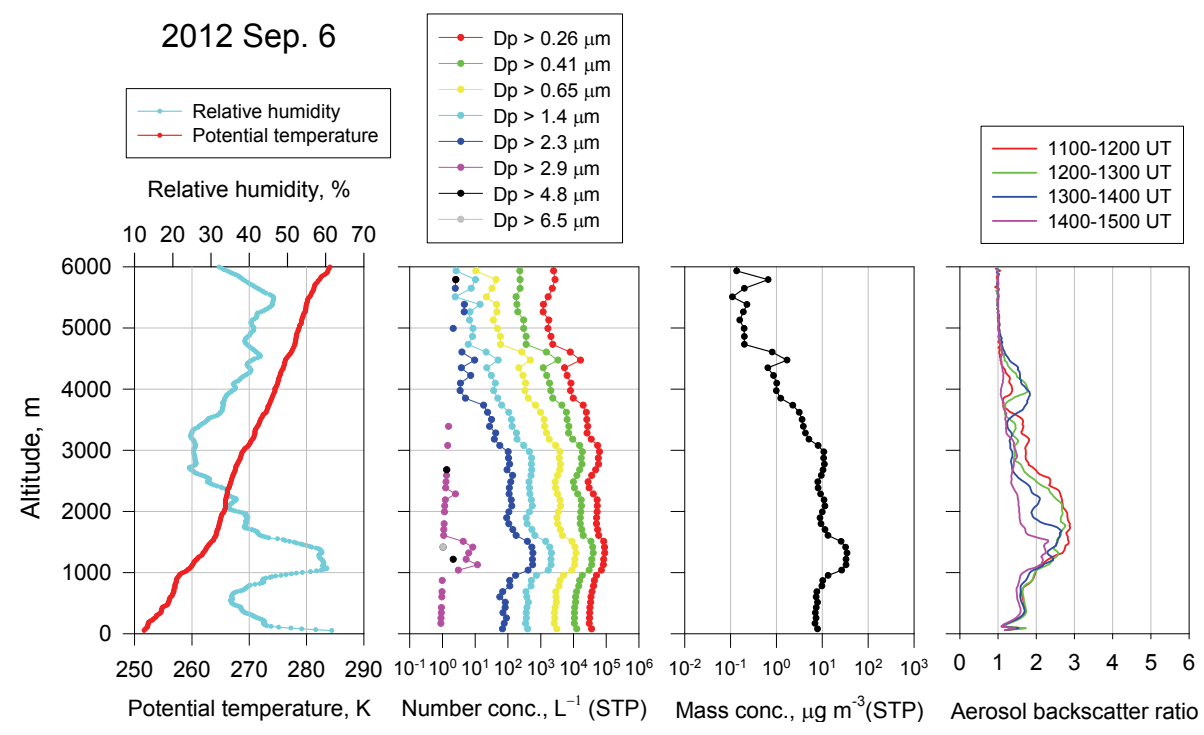

Fig. 5. Vertical variations of air temperature, relative humidity, aerosol number concentration, mass concentration, and backscatter ratio over Syowa Station on 6 September 2012.

were taken on 6 September during the decline of aerosol enhancement. Similar to the case in August, vertical profiles of potential temperature, relative humidity and aerosol number concentrations suggest that several layers were distributed over Syowa Station. Vertical features of the potential temperature imply that the height of the boundary layer was approximately $960 \mathrm{~m}$ on 6 September. Vertical features of the aerosol number concentrations between the surface and $4 \mathrm{~km}$ altitude imply the presence of several aerosol layers as fol- lows: surface- $-1000 \mathrm{~m}$ (probably a boundary layer), 1000$1500 \mathrm{~m}, 1600-2200 \mathrm{~m}, 2300-2600 \mathrm{~m}, 2700-3100 \mathrm{~m}, 3200$ $3800 \mathrm{~m}$, and $>3800 \mathrm{~m}$. The layered structures of aerosol number concentrations corresponded well to the vertical features of potential temperature and the relative humidity. The respective aerosol number concentrations in $D_{\mathrm{p}}>0.26 \mu \mathrm{m}$ in the layers were approximately $3.0 \times 10^{4}-4.3 \times 10^{4}$, $8.8 \times 10^{4}, 5.0 \times 10^{4}, 2.7 \times 10^{4}, 5.8 \times 10^{4}, 2.7 \times 10^{4}$, and $8 \times 10^{3} \mathrm{~L}^{-1}$. Mass concentrations were ca. $7 \mu \mathrm{g} \mathrm{m}^{-3}$ below 
$700 \mathrm{~m}$, ca. $34 \mu \mathrm{g} \mathrm{m}^{-3}$ at $1100-1600 \mathrm{~m}$, and $7-12 \mu \mathrm{g} \mathrm{m}^{-3}$ at $1650-3050 \mathrm{~m}$. Considerable aerosol enhancement was found in the lower free troposphere $(1000-1600 \mathrm{~m})$. Actually, higher number concentrations were found, respectively, at $1000-1600 \mathrm{~m}$, for instance $9.0 \times 10^{4}$ and $575 \mathrm{~L}^{-1}$ in $D_{\mathrm{p}}>0.26$ and $>2.3 \mu \mathrm{m}$. Furthermore, a higher aerosol backscatter ratio (2.1-2.3) and the highest mass concentrations (ca. $34 \mu \mathrm{g} \mathrm{m}^{-3}$ ) were observed at that altitude. High number concentrations and mass concentrations in balloonborne aerosol measurements were obtained up to ca. $3100 \mathrm{~m}$, although a slight decrease of aerosol number concentrations was observed at $2300-2600 \mathrm{~m}$. In contrast to aerosol enhancement in August, the margin of the top of the aerosolenhanced layer was not clear in this case. Above $3200 \mathrm{~m}$, the aerosol number concentrations and mass concentrations decreased gradually with altitude. Above $3100 \mathrm{~m}$, mass concentrations decreased gradually from 10 to $<1 \mu \mathrm{g} \mathrm{m}^{-3}$. Although mass concentrations at altitudes higher than $4 \mathrm{~km}$ were lower than $0.1 \mu \mathrm{g} \mathrm{m}^{-3}$ in the case on 14 August (Fig. 2), they were $0.1-0.2 \mu \mathrm{g} \mathrm{m}^{-3}$ on 6 September. Vertical features of the hourly mean backscatter ratio at 14:00-15:00 UT coincided well with the vertical distributions of aerosol number concentrations and mass concentrations.

Furthermore, the number concentrations of $D_{\mathrm{p}}>2.3 \mu \mathrm{m}$ at the surface to $4 \mathrm{~km}$ on 6 September were 1-2 orders lower than those on 14 August, although the number concentrations of fine mode (e.g., $D_{\mathrm{p}}>0.26 \mu \mathrm{m}$ ) in this case were similar to or higher than those of the case on 14 August. As discussed above, a lower number concentration in coarse mode on 6 September might result from the dry deposition of coarse particles during transport. This difference in size distribution implies that air masses on 6 September were aged relative to the air mass on 14 August. Details are discussed in a later section.

\subsubsection{Air mass history of the aerosol-enhanced layer}

Before aerosol enhancement on 4 September, Syowa Station was located in the ridge of anticyclone (shown in Supplement). Different from the case in August, the cyclone was located around $55^{\circ} \mathrm{E}, 65^{\circ} \mathrm{S}$ at 00:00 UT on 4 September. The cyclone, however, also suddenly weakened in this case. Considering isobar distributions around Syowa Station before the occurrence of the aerosol enhancement, poleward flow might occur in $70-80^{\circ} \mathrm{E}$. To elucidate the air mass history of the aerosol-enhanced layer, the 5-day backward trajectory was computed as shown in Fig. 6. Air masses of the aerosol-enhanced layer (below $2400 \mathrm{~m}$ a.s.l.) at 00:00 UT on 6 September were transported from the boundary layer via sea-ice regions and coastal line. Poleward flow from $<60^{\circ} \mathrm{S}$ occurred along ca. $70-80^{\circ} \mathrm{E}$ line on 2-3 September. End-points of the 5-day backward trajectory from the aerosol-enhanced layer were distributed around $45-65^{\circ} \mathrm{S}$. According to satellite measurements by AMSR2 (Advanced Microwave Scanning Radiometer; e.g., http://
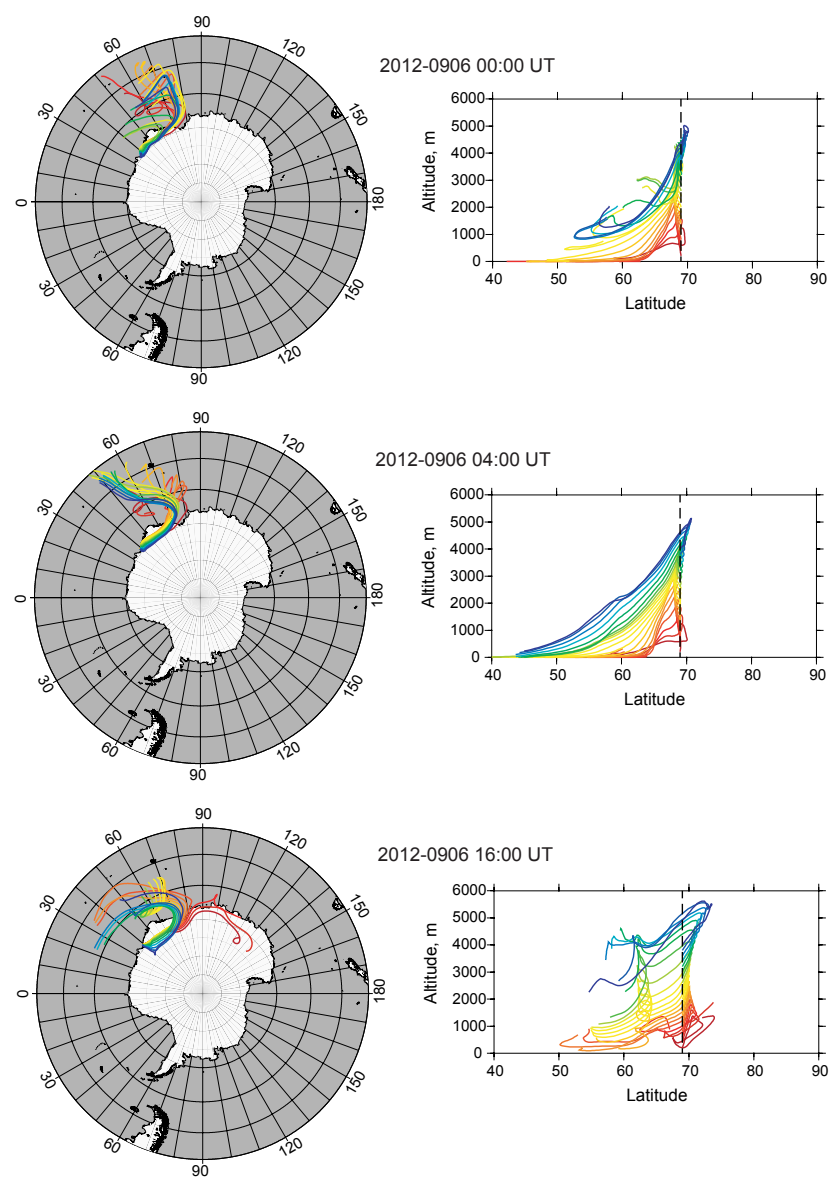

Fig. 6. Examples of 5-day backward trajectory at 00:00 UT on 6 September, at 04:00 UT on 6 September, and at 16:00 UT on 6 September. Dashed line represents latitude of Syowa Station $\left(69^{\circ} \mathrm{S}\right)$. Trajectories are color coded to correspond to initial height over Syowa Station.

www.iup.uni-bremen.de:8084/amsr/\#Antarctic) and Comiso (2010), the sea-ice area in September was usually extended to ca. $60^{\circ} \mathrm{S}$ at $70-90^{\circ} \mathrm{E}$. Therefore, air masses came from the boundary layer $(<1000 \mathrm{~m})$ over sea-ice and open-sea areas. By contrast, air masses above $2400 \mathrm{~m}$ show transport above ca. $1000 \mathrm{~m}$ (probably the free troposphere) over sea-ice regions. This height of transport was well consistent with vertical features of the aerosol backscatter ratio. After air masses came close to the coasts on 3 September, aerosol-enhanced air moved slowly to Syowa Station, especially during the period 4-6 September.

As presented in Fig. 5, a high aerosol backscatter ratio was observed above $3 \mathrm{~km}$ for approximately $11 \mathrm{~h}$ on 6 September. The 5-day backward trajectory from the aerosol-enhanced layer at 04:00 UT on 6 September showed a similar transport pathway from sea-ice and open-sea areas. Especially, air masses above $3 \mathrm{~km}$ were transported from the boundary layer over the open-sea area $\left(<50^{\circ} \mathrm{S}\right)$. Air masses of the aerosolenhanced layer above $3 \mathrm{~km}$ were located at altitudes higher 
than $1300 \mathrm{~m}$ over $60^{\circ} \mathrm{S}$ (near sea-ice margin). Therefore, the travel time in the boundary layer over the sea-ice area might be shorter. By contrast, air masses of the aerosol-enhanced layer below $3 \mathrm{~km}$ might have traveled for a longer time in the boundary layer over the sea-ice area.

As depicted in Fig. 6, the transport distance for $24 \mathrm{~h}$ was shorter for the prior 1-3 days than for the prior 4-5 days. For the backward trajectory at 04:00 UT on 6 September, for example, the distances between locations every $24 \mathrm{~h}$ for the previous 5 days were approximately 480, 500, 380, 1500, and $1300 \mathrm{~km}$, respectively. Mean wind speeds can be estimated as follows: $5.6,5.8,4.4,17.4$ and $15.0 \mathrm{~m} \mathrm{~s}^{-1}$. Consequently, strong winds might occur mostly in sea-ice regions. High sea-salt concentrations were observed under strong wind conditions. Therefore, poleward flow over sea-ice regions suggests that large amounts of sea-salt particles were released from sea-ice surfaces on 2-3 September. Consequently, the dispersion of sea-salt particles from sea-ice and open-sea surfaces might contribute considerably to aerosol enhancement below $3 \mathrm{~km}$ during the period 5-7 September, similar to the aerosol enhancement on August 2012 and the other cases (Hara et al., 2010). Considering the vertical motion over the sea-ice area during transport and considering the vertical features of the aerosol backscatter ratio, the release of sea-salt particles from the sea-ice surface and opensea surface might respectively engender aerosol enhancement below $2.7 \mathrm{~km}$ and in $2.7-4 \mathrm{~km}$. Particularly, the dispersion of sea-salt particles from sea-ice is expected to make a significant contribution to strong aerosol enhancement below $2.7 \mathrm{~km}$. Furthermore, high concentrations of sea-salt particles (e.g., $\mathrm{Na}^{+}$) and nonvolatile particles (probably seasalt particles) were observed under the strong wind conditions (i.e., blizzard and storm) at Syowa Station (Hara et al., 2004, 2011a). Thus, sea-salt particles might be released only slightly from the sea-ice surface under calm wind conditions. Therefore, the concentrations of the dispersed sea-salt particles might decrease gradually through dry deposition during westward transport along the coasts. This likelihood is consistent with the lower concentrations in $D_{\mathrm{p}}>2.0$ and $3.0 \mu \mathrm{m}$ in this case, as described above.

After 13:00 UT on 6 September, the aerosol-enhanced layer became thinner, as shown in Figs. 4 and 5. Backward trajectory results show that air masses above the aerosolenhanced layer $(>1800 \mathrm{~m}$ ) traveled mostly at altitudes higher than $2000 \mathrm{~m}$ over the sea-ice area. In addition, the air mass origin and transport pathways were shifted gradually over the Antarctic continent. On 7 September, the origin of the air mass above $2000 \mathrm{~m}$ moved to the free troposphere over the Antarctic continent (not shown). Therefore, transport of clean air from the free troposphere might cause termination of the aerosol enhancement in the free troposphere over Syowa Station.
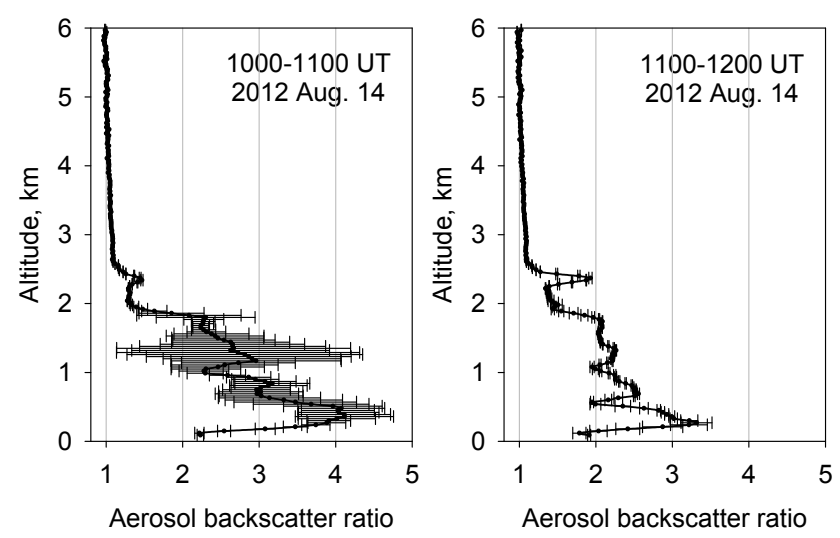

Fig. 7. Vertical profiles of aerosol backscatter ratio at 10:00-11:00 UT and 11:00-12:00 UT on 14 August 2012 over Syowa Station, Antarctica. Error bars show the standard deviation.

\subsection{Seasonal and vertical features of occurrence of aerosol enhancement in the lower troposphere}

Vertical features of Antarctic haze over Syowa Station in the two cases were discussed above. The two simultaneous measurements, however, were conducted for too short a time to elucidate the occurrence of Antarctic haze, or to estimate its contribution quantitatively. We attempted to estimate the seasonal and vertical features of the occurrence of the aerosol-enhanced layer in 2012 over Syowa Station using MPL data. Because MPL was operated continuously, with the exception of interruptions for periodical maintenance, MPL data must be screened for influences from factors including drifting snow, precipitation, and clouds before discussion about aerosol enhancement. Figure 7 depicts examples of vertical profiles of aerosol backscatter ratio during the occurrence of Antarctic haze on 14 August 2012. Although the standard deviation in the aerosol backscatter ratio varied greatly in the vertical profile at 10:00-11:00 UT (Fig. 7a), the standard deviation was remarkably smaller in the profile at 11:00-12:00 UT (Fig. 7b). According to Ishii et al. (1999), the Arctic haze layer had a stable structure. Actually, the layered structure in Antarctic haze was stable except for the occurrence of precipitation and clouds, as shown in Figs. 1 and 4. Because of the fluctuating structure of drifting snow, precipitation, and clouds, the standard deviation can vary greatly at altitudes where drifting snow, precipitation, and clouds occur. Furthermore, a high aerosol backscatter ratio is obtained at layers with drifting snow, precipitation, and clouds. Consequently, MPL data with drifting snow, precipitation, and clouds might be screened using the hourly mean aerosol backscatter ratio and standard deviation.

Second, we verified the relation between the hourly mean aerosol backscatter ratio and standard deviation to estimate threshold values for data screening. Figure 8 presents an example of the relation between the hourly mean aerosol backscatter ratio and the standard deviation in MPL data at 


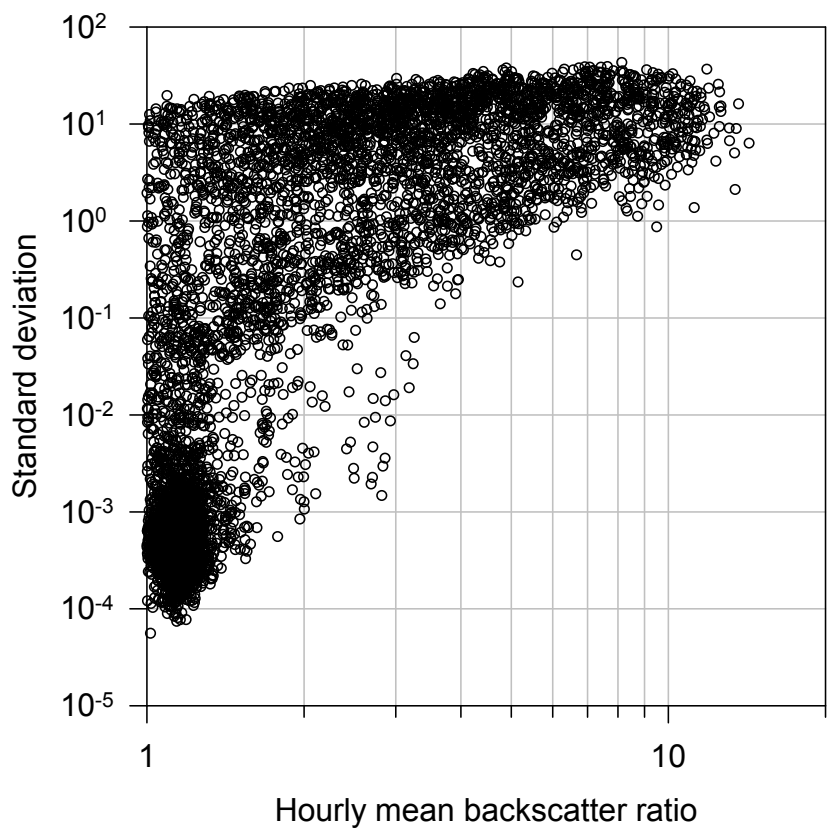

Fig. 8. Relation between the hourly mean aerosol backscatter ratio and standard deviation at $500 \mathrm{~m}$ above ground level over Syowa Station, Antarctica in 2012.

$500 \mathrm{~m}$ above ground level. A high aerosol backscatter ratio was observed mostly at standard deviations larger than 0.1 . The relation was similar at other altitudes. Here, MPL data with standard deviations larger than 0.1 were filtered as "appearance of drifting snow, precipitation, and clouds".

Third, we examined the threshold value to divide between unusual aerosol enhancement (Antarctic haze) and nonhaze conditions. A high aerosol backscatter ratio and high aerosol number concentrations were obtained in the boundary layer and lower free troposphere, as shown in Figs. 1 and 5, and Hara et al. (2011b). However, the top of the aerosol-enhanced layer varied greatly at the top of boundary layer and lower free troposphere. Most of the Antarctic haze layer occurred in the upper boundary layer and lower free troposphere, as described above. Therefore, we estimate the threshold values using aerosol backscatter ratio at 500-1000 m. Figure 9 depicts an example of a histogram of an aerosol backscatter ratio in filtered MPL data at $500 \mathrm{~m}$ in 2012. The annual mean of the aerosol backscatter ratio over Syowa Station was 1.21 (median, 1.17) at $500 \mathrm{~m}$ in 2012. In this study, the 95th percentile value at $500 \mathrm{~m}(1.55)$ was used as the threshold value to identify "unusual aerosol enhancement". The 95th percentile value at $500-1000 \mathrm{~m}$ was $1.55 \pm 0.02$. The two cases of Antarctic haze in Figs. 1 and 4 can be taken by these criteria. Therefore, the criteria might be appropriate for identification of "unusual aerosol enhancement".

Figure 10 depicts seasonal and vertical features of cumulative time of MPL data with an aerosol backscatter ratio higher than 1.55 and standard deviation lower than 0.1 .

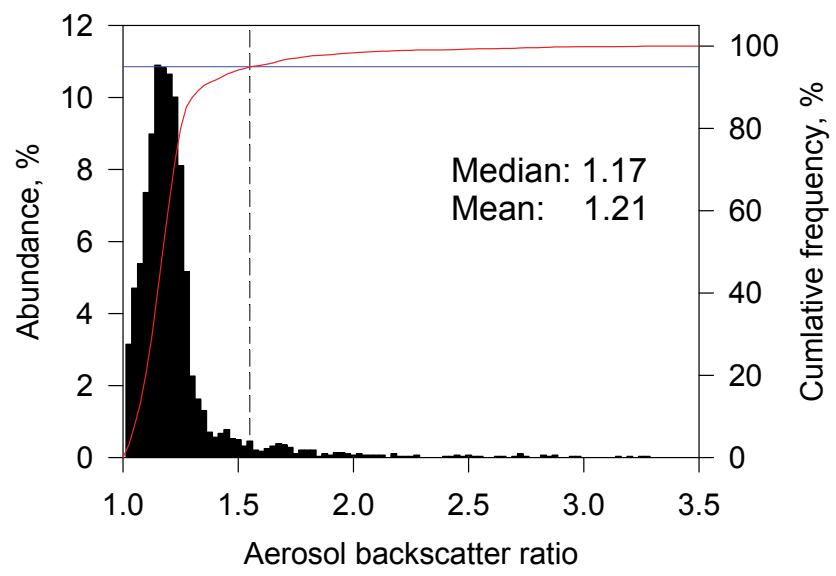

Fig. 9. Histogram of the filtered aerosol backscatter ratio at $500 \mathrm{~m}$ over Syowa Station, Antarctica. The red line, horizontal blue line, and vertical dashed line respectively indicate cumulative frequency, 95th percentile and value of 1.55 in the aerosol backscatter ratio.

Clouds and precipitation occurred occasionally in the upper boundary layer and free troposphere even during the aerosol enhancement (Antarctic haze). Therefore, the cumulative time was likely to have been underestimated relative to the actual duration of Antarctic haze. The cumulative time in the lower troposphere $(<2 \mathrm{~km})$ over Syowa Station increased gradually during the period April-September in 2012. Then the cumulative time dropped in October. In July-September, aerosol enhancement occurred markedly at altitudes lower than $2 \mathrm{~km}$. Particularly, the aerosol-enhanced layer occurred frequently in September and was distributed up to $4 \mathrm{~km}$. A slightly high cumulative time was observed at around $5 \mathrm{~km}$ in 2012 . Considering the vertical structure of the cumulative time around $5 \mathrm{~km}$, the layer around $5 \mathrm{~km}$ might have been a cirrus layer. The typical top altitudes of the Antarctic haze layer might have been $1-2.5 \mathrm{~km}$, although more data must be obtained to characterize vertical features of Antarctic haze. Indeed, top altitudes of Antarctic haze and the aerosol-enhanced layer were described as below approximately $3 \mathrm{~km}$ in previous reports by Yamanouchi et al. (1999), and Hara et al. (2011b). Therefore, the case of 6 September 2012 (shown in Figs. 4 and 5) might be identified as that with the greatest thickness of Antarctic haze. With the suggestion that wind-blowing release of sea-salt particles from sea ice contributes significantly to Antarctic haze, as discussed above, seasonal features of the cumulative time might be associated with the seasonal variation of sea-ice extent. Indeed, the sea-ice extent off Syowa Station reaches a maximum level usually in September (satellite measurements by AMSR2 (http://www.iup.uni-bremen.de: 8084/amsr/\#Antarctic); Comiso, 2010). Vertical features of the cumulative time show that the aerosol-enhanced layer occurred frequently at altitudes lower than ca. $0.9 \mathrm{~km}$, which might be coincident with the altitude of the top of the boundary layer over Syowa Station during winter and spring. 


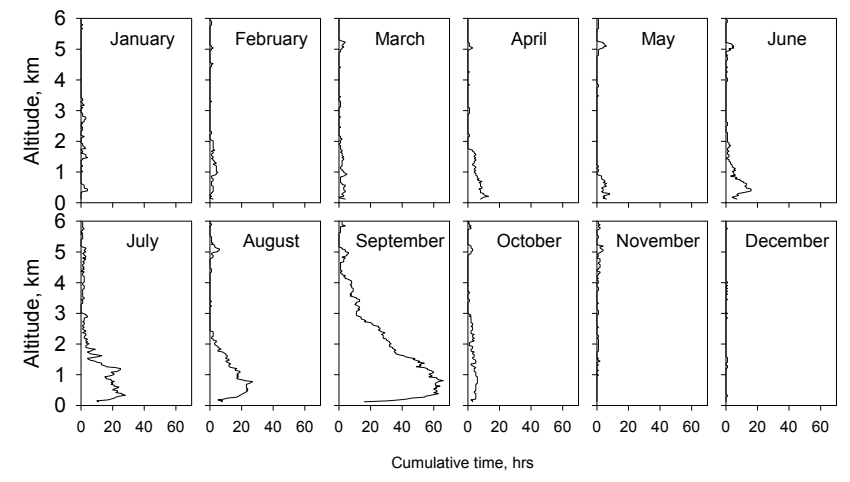

Fig. 10. Seasonal and vertical features of cumulative time of MPL data with aerosol backscatter ratio higher than 1.55 and standard deviation lower than 0.1 in 2012 over Syowa Station, Antarctica.

A high cumulative time at heights above $0.9 \mathrm{~km}$ suggests that Antarctic haze occurred in the lower free troposphere (mainly lower than $3 \mathrm{~km}$ ), similar to the two cases in this study.

\subsection{Implications of aerosol enhancement in the lower troposphere}

Dispersion of sea-salt particles from sea-ice surface contributed significantly to aerosol enhancement in the lower troposphere over Syowa Station. Particularly sea-salt particles of sea-ice origin were distributed mostly at altitudes lower than $2.5 \mathrm{~km}$ in both cases. This vertical distribution provides important evidence to ascertain sea-salt and halogen chemistry in the Antarctic regions and to infer results from ice core record data.

As described above, large amounts of sea-salt particles, especially those released from sea-ice surfaces, were present in the aerosol-enhanced layer. Particularly, the occurrence of Antarctic haze increased significantly in September. Previous aerosol measurements near the surface in the Antarctic coasts indicated the high concentrations of sea-salt particles $\left(\mathrm{Na}^{+}\right)$ in April-October (Wagenbach et al., 1988, Rankin and Wolff, 2003; Hara et al., 2004). Similar to this study, high $\mathrm{Na}^{+}$concentrations were observed in late winter at Halley Station (Rankin and Wolff, 2003). The seasonal features of sea-salt particles, however, included the high sea-salt concentrations under strong wind conditions. Hara et al. (2010) showed that Antarctic haze events occurred mostly in July-September at Syowa Station. Considering presence of sulfate-depleted seasalt particles originating from sea ice in winter-spring and in Antarctic haze, the seasonal features of occurrence of the aerosol-enhanced layer might be associated with sea-ice extent, surface conditions on sea-ice surface (e.g., formation of frost flower), and meteorological conditions (e.g., cyclone approach and sudden decline), as discussed above and by Hara et al. (2010, 2012). Further field measurements and reanalysis of the archived aerosol data would provide a better understanding of the occurrence of Antarctic haze (aerosol enhancement). Although this study focused on occurrence of Antarctic haze over Syowa Station in 2012, the occurrence of Antarctic haze (aerosol enhancement) and its vertical and seasonal features over longer periods will be discussed elsewhere.

The marked enhancement of sea-salt particles in Antarctic haze can induce substantial release of reactive halogen species through heterogeneous reactions (e.g., Simpson et al., 2007; Saiz-Lopez et al., 2008). Reactive halogen species such as $\mathrm{BrO}$ and $\mathrm{Br}$ relate closely to ozone depletion and the oxidation of dimethyl sulfide in the lower troposphere (e.g., Simpson et al., 2007; Saiz-Lopez et al., 2008; Read et al., 2008). Actually, our previous work indicated that $\mathrm{O}_{3}$ concentrations near the surface dropped simultaneously during the Antarctic haze after polar sunrise (Hara et al., 2010). In addition, $\mathrm{O}_{3}$ depletion in the coastal Antarctic region was extended upward to ca. $3 \mathrm{~km}$ (Wessel et al., 1998; Jones et al., 2010). The vertical extent of $\mathrm{O}_{3}$ depletion corresponded approximately to the vertical structure of the aerosol-enhanced layer in this study. Therefore, it is expected that aerosol enhancement (Antarctic haze) with large amounts of sea-salt particles in the lower troposphere plays important roles in atmospheric chemical cycles that prevail along the Antarctic coasts.

Sea salt has often been used as an index of sea-ice extent in ice core records (e.g., Wolff et al., 2006). Sea-salt particles originated from sea ice are fractionated in winter-spring, as suggested by Hara et al. (2012) and references therein. Although the presence of the fractionated sea-salt particles was identified in inland areas (Hara et al., 2004; Udisti et al., 2012), transport processes of sea-salt particles from sea-ice areas to inland areas have not been well discussed. To elucidate the transport processes of sea-salt particles derived from sea ice in the aerosol-enhanced layer, we calculated 5-day forward trajectory from the aerosol-enhanced layer in August and September over Syowa Station (not shown). The trajectories in both cases indicated that air parcels were transported not to inland areas but to the boundary layer over sea-ice and open-sea areas. Because only two cases were discussed in this study, we cannot conclude whether sea-salt particles from sea ice in the aerosol-enhanced layer were usually transported to inland areas, or not. As described earlier, the aerosol-enhanced layer was observed at altitudes lower than ca. $2.7 \mathrm{~km}$ in this study. This altitude is useful as an index to discuss transport of sea-salt particles from sea-ice and coastal areas to inland areas if aerosol enhancement by dispersion of sea-salt particles from sea ice occurs usually at altitudes lower than $2.7 \mathrm{~km}$ around the Antarctic coasts. Indeed, air masses with high sea-salt concentrations $\left(\mathrm{Na}^{+}\right)$at Dome $\mathrm{F}$ were located in the lower free troposphere $(1600-3500 \mathrm{~m})$ over the coastal line (Hara et al., 2004).

Aerosol-enhancement conditions were produced by the substantial release of sea-salt particles from the ocean and sea-ice surfaces under strong winds during transport. 
Poleward flow can engender the transport of humid air into Antarctic coasts along with mixing of large amounts of seasalt particles. During aerosol enhancement, clouds appeared occasionally in the upper boundary layer and lower free troposphere. Considering the significant transport of water vapor by poleward flow and dispersion of sea-salt particles in the aerosol-enhanced layer, cloud activation might be promoted in the aerosol-enhanced layer. Antarctic haze can occur on other Antarctic coasts. Therefore, cloud appearance in the Antarctic haze might affect atmospheric radiation budgets temporarily in coastal Antarctic regions.

\section{Concluding remarks}

Simultaneous aerosol measurements were taken on $14 \mathrm{Au}-$ gust and 6 September 2012 at Syowa Station, Antarctica, using ground-based OPC, balloon-borne OPC, and MPL under aerosol-enhanced conditions. Remarkable aerosol enhancement was identified in the boundary-lower free troposphere (near the surface-2.7 km) in both cases. Moreover, high aerosol number concentrations, mass concentrations and an aerosol backscatter ratio were observed up to ca. $4 \mathrm{~km}$ on 6 September. Mass concentrations in the aerosol-enhanced layer increased to larger than $10 \mu \mathrm{g} \mathrm{m}^{-3}$. The mass concentrations reached $62 \mu \mathrm{g} \mathrm{m}^{-3}$ in the boundary layer on $14 \mathrm{Au}-$ gust. In both cases, aerosol enhancement was likely to be associated with large amounts of sea-salt particles from seaice and ocean surfaces under strong winds during poleward flow by a cyclone approach. Particularly, dispersion of seasalt particles from the sea-ice surface might make an important contribution to the occurrence of aerosol enhancement near the surface and up to $2.7 \mathrm{~km}$.

Year-round MPL measurements in 2012 revealed the occurrence of high aerosol enhancement in the boundary layer and free troposphere over Syowa Station. Marked aerosol enhancement was identified in July-September. Vertical features of the cumulative time of high aerosol backscatter ratio by aerosol enhancement showed that an aerosol enhanced layer occurred frequently at the altitudes lower than $0.9 \mathrm{~km}$, which might correspond to the boundary layer height during the winter-spring period(e.g., Hara et al., 2011). Furthermore, the aerosol-enhanced layer was distributed up to ca. $4 \mathrm{~km}$ in September over Syowa Station. Considering that aerosol enhancement (Antarctic haze) is likely caused by vertical mixing of sea-salt particles released from the sea-ice surface, Antarctic haze might play an important role in the atmospheric radiation budget by direct its effect and cloud formation, and atmospheric chemistry through heterogeneous reactions on sea-salt particles. For a better understanding, it is necessary to obtain more knowledge related to the vertical structure of the aerosol-enhanced layer, their seasonal features, and transport processes in the troposphere over the Antarctic coasts. Further field measurements and reanalysis of the archived aerosol data are required to characterize the usual occurrence of Antarctic haze, and to understand the impact on atmospheric chemistry, radiation budgets, and climate change in the Antarctic regions.

\section{Supplementary material related to this article is available online at http://www.atmos-chem-phys.net/14/ 4169/2014/acp-14-4169-2014-supplement.pdf.}

Acknowledgements. We would like to thank C. Ikeda, T. Fujita, and other JARE53 wintering members for field operations at Syowa Station, Antarctica. The authors gratefully acknowledge the NOAA Air Resources Laboratory (ARL) for the provision of the HYSPLIT transport and dispersion model and/or READY website (http://ready.arl.noaa.gov) used in this publication. This work was also supported by a Grant-in-Aid for Scientific Research (B) (no. 22310013, PI: K. Hara) from the Ministry of Education, Culture, Sports, Science and Technology of Japan. We thank two anonymous reviewers for assisting in the evaluation of this paper.

Edited by: P. DeCarlo

\section{References}

Bodhaine, B. A.: Aerosol absorption measurements at Barrow, Mauna Loa and the South Pole, J. Geophys. Res., 100, 89678975, 1995.

Campbell, J. R., Hlavka, D. L., Welton, E. J., Flynn, C. J., Turner, D. D., Spinhirne, J. D., Scott, V. S., and Hwang, I. H.: Full-time, eye-safe cloud and aerosol lidar observation at Atmospheric Radiation Measurement Program sites: Instruments and data processing, J. Atmos. Ocean. Tech., 19, 431-442, 2002.

Comiso, J.: Characteristics and variability of the sea ice cover, in: Polar oceans from space, 295-363, Springer, New York, USA, 2010.

Draxler, R. R. and Rolph, G. D.: HYSPLIT (HYbrid Single-Particle Lagrangian Integrated Trajectory) Model access via NOAA ARL READY Website (http://ready.arl.noaa.gov/HYSPLIT. php), NOAA Air Resources Laboratory, Silver Spring, MD, 2013.

Fernald, F. G.: Analysis of atmospheric lidar observations: Some comments, Appl. Optics., 23, 652-653, 1984.

Fiebig, M., Lunder, C. R., and Stohl, A.: Tracing biomass burning aerosol from South America to Troll Research Station, Antarctica, Geophys. Res. Lett., 36, L14815, doi:10.1029/2009GL038531, 2009.

Grönlund, A., Nilsson, D., Koponen, I. K., Virkkula, A., and Hansson, M.: Aerosol dry deposition measured with eddy-covariance technique at Wasa and Aboa, Dronning Maud Land, Antarctica, Ann. Glaciol., 35, 355-361, 2002.

Hara, K., Osada, K., Kido, M., Hayashi, M., Matsunaga, K., Iwasaka, Y., Yamanouchi, T., Hashida, G., and Fukatsu, T.: Chemistry of sea-salt particles and inorganic halogen species in Antarctic regions: Compositional differences between coastal and inland stations, J. Geophys. Res., 109, D20208, doi:10.1029/2004JD004713, 2004. 
Hara, K., Osada, K., Yabuki, M., Hashida, G., Yamanouchi, T., Hayashi, M., Shiobara, M., Nishita-Hara, C., and Wada, M.: Haze episodes at Syowa Station, coastal Antarctica: Where did they come from?, J. Geophys. Res., 115, D14205, doi:10.1029/2009JD012582, 2010.

Hara, K., Osada, K., Nishita-Hara, C., Yabuki, M., Hayashi, M., Yamanouchi, T., Wada, M., and Shiobara, M.: Seasonal features of ultrafine particle volatility in the coastal Antarctic troposphere, Atmos. Chem. Phys., 11, 9803-9812, doi:10.5194/acp-11-98032011, 2011a.

Hara, K., Osada, K., Nishita-Hara, C., and Yamanouchi, T.: Seasonal variations and vertical features of aerosol particles in the Antarctic troposphere, Atmos. Chem. Phys., 11, 5471-5484, doi:10.5194/acp-11-5471-2011, 2011 b.

Hara, K., Osada, K., Yabuki, M., and Yamanouchi, T.: Seasonal variation of fractionated sea-salt particles on the Antarctic coast, Geophys. Res. Lett., 39, L18801, doi:10.1029/2012GL052761, 2012.

Hara, K., Osada, K., and Yamanouchi, T.: Tethered balloon-borne aerosol measurements: seasonal and vertical variations of aerosol constituents over Syowa Station, Antarctica, Atmos. Chem. Phys., 13, 9119-9139, doi:10.5194/acp-13-9119-2013, 2013.

Ishii, S., Shibata, T., Nagai, T., Mizutani, K., Itabe, T., Hirota, M., Fujimoto, T., and Uchino, O.: Arctic haze and clouds observed by lidar during four winter seasons of 1993-1997, at Eureka, Canada, Atmos. Environ., 33, 2459-2470, doi:10.1016/S13522310(98)00397-5, 1999.

Ito, T.: Antarctic Submicron Aerosols and Long-Range Transport of Pollutants, Ambio, 18, 34-41, 1989.

Ito, T.: Size distribution of Antarctic submicron aerosols, Tellus B, 45, 145-159, doi:10.1034/j.1600-0889.1993.t01-1-00007.x, 1993.

Iwasaki, S., Maruyama, K., Hayashi, M., Ogino, S.-Y., Ishimoto, H., Tachibana, Y., Shimizu, A., Matsui, I., Sugimoto, N., Yamashita, K., Saga, K., Iwamoto, K., Kamiakito, Y., Chabangborn, A., Thana, B., Hashizume, M., Koike, T., and Oki, T.: Characteristics of aerosol and cloud particle size distributions in the tropical tropopause layer measured with optical particle counter and lidar, Atmos. Chem. Phys., 7, 3507-3518, doi:10.5194/acp7-3507-2007, 2007.

Jones, A. E., Anderson, P. S., Wolff, E. W., Roscoe, H. K., Marshall, G. J., Richter, A., Brough, N., and Colwell, S. R.: Vertical structure of Antarctic tropospheric ozone depletion events: characteristics and broader implications, Atmos. Chem. Phys., 10, 7775-7794, doi:10.5194/acp-10-7775-2010, 2010.

Omar, A. H., Winker, D. M., Kittaka, C., Vaughan, M. A., Liu, Z., Hu, Y., Trepte, C. R., Rogers, R. R., Ferrare, R. A., Lee, K.-P., Kuehn, R. E, and Hostetler, C. A.: The CALIPSO Automated Aerosol Classification and Lidar Ratio Selection Algorithm, J. Atmos. Ocean. Tech., 26, 1994-2014, 2009.

Osada, K., Hayashi, M., Shiobara, M., Hara, K., Wada, M., Hashida, G., Morimoto, S., Yabuki, M., and Yamanouchi, T.: Atmospheric observation room for clean air at Syowa Station, East Antarctica (in Japanese), Antarctic Records, 50, 86-102, 2006.

Osada, K., Hayashi, M., Hara, K., Yabuki, M., Wada, M., Shiobara, M., Yamanouchi, T., and Fujita, K.: Seasonal variation of coarse aerosol particle concentration at Syowa station, Antarctica, Antarctic Records, 54, 487-497, 2010 (in Japanese).
Pereira, E. B., Evangelista, H., Pereira, K. C. D., Cavalcanti, I. F. A., and Setzer, A. W.: Apportionment of black carbon in the South Shetland Islands, Antarctic Peninsula, J. Geophys. Res., 111, D03303, doi:10.1029/2005JD006086, 2006.

Rankin, A. and Wolff, E.: A year-long record of size-segregated aerosol composition at Halley, Antarctica, J. Geophys. Res., 108, 4775, doi:10.1029/2003JD003993, 2003.

Read, K. A., Lewis, A. C., Bauguitte, S., Rankin, A. M., Salmon, R. A., Wolff, E. W., Saiz-Lopez, A., Bloss, W. J., Heard, D. E., Lee, J. D., and Plane, J. M. C.: DMS and MSA measurements in the Antarctic Boundary Layer: impact of BrO on MSA production, Atmos. Chem. Phys., 8, 2985-2997, doi:10.5194/acp-82985-2008, 2008.

Saiz-Lopez, A., Plane, J. M. C., Mahajan, A. S., Anderson, P. S., Bauguitte, S. J.-B., Jones, A. E., Roscoe, H. K., Salmon, R. A., Bloss, W. J., Lee, J. D., and Heard, D. E.: On the vertical distribution of boundary layer halogens over coastal Antarctica: implications for $\mathrm{O}_{3}, \mathrm{HO}_{\mathrm{x}}, \mathrm{NO}_{\mathrm{x}}$ and the $\mathrm{Hg}$ lifetime, Atmos. Chem. Phys., 8, 887-900, doi:10.5194/acp-8-887-2008, 2008.

Seinfeld, J. H. and Pandis, S. N.: Dry deposition, in: Atmospheric chemistry and phsics from air pollution to climate change second edition, Wiley-Interscience Publication, New Jersey, 900931, 2006.

Shibata, T., Sato, K., Kobayashi, H., Yabuki, M., and Shiobara, M.: Antarctic polar stratospheric clouds under temperature perturbation by nonorographic inertia gravity waves observed by micropulse lidar at Syowa Station, J. Geophys. Res., 108, 4105, doi:10.1029/2002JD002713, 2003.

Shibata, T., Hayashi, M., Naganuma, A., Hara, N., Hara, K., Hasebe, F., Shimizu, K., Komala, N., Inai, Y., Vömel, H., Hamdi, S., Iwasaki, S., Fujiwara, M., Shiotani, M., Ogino, S.-Y., and Nishi, N.: Cirrus cloud appearance in a volcanic aerosol layer around the tropical cold point tropopause over Biak, Indonesia, in January 2011, J. Geophys. Res., 117, D11209, doi:10.1029/2011JD017029, 2012.

Shiobara, M., Yabuki, M., and Kobayashi, H.: A polar cloud analysis based on Micro-pulse Lidar measurements at Ny-Ålesund, Svalbard and Syowa, Antarctica, Phys. Chem. Earth, 28, 12051212, 2003.

Simpson, W. R., von Glasow, R., Riedel, K., Anderson, P., Ariya, P., Bottenheim, J., Burrows, J., Carpenter, L. J., Frieß, U., Goodsite, M. E., Heard, D., Hutterli, M., Jacobi, H.-W., Kaleschke, L., Neff, B., Plane, J., Platt, U., Richter, A., Roscoe, H., Sander, R., Shepson, P., Sodeau, J., Steffen, A., Wagner, T., and Wolff, E.: Halogens and their role in polar boundary-layer ozone depletion, Atmos. Chem. Phys., 7, 4375-4418, doi:10.5194/acp-74375-2007, 2007.

Tomasi, C., Lupi, A., Mazzola, M., Stone, R. S., Dutton, E. G., Herber, A., Radionov, V. F., Holben, B. N., Sorokin, M. G., Sakerin, S. M., Terpugova, S. A., Sobolewski, P. S., Lanconelli, C., Petkov, B. H., Busetto, M., and Vitale, V.: An update on polar aerosol optical properties using POLAR-AOD and other measurements performed during the International Polar Year, Atmos. Environ., 52, 29-47, 2012.

Udisti, R., Dayan, U., Becagli, S., Busetto, M., Frosini, D., Legrand, M., Lucarelli, F., Preunkert, S., Severi, M., Traversi, R., and Vitale, V.: Sea spray aerosol in central Antarctica. Present atmospheric behaviour and implications for paleoclimatic reconstructions, Atmos. Environ., 52, 109-120, 2012. 
van der Werf, G. R., Randerson, J. T., Giglio, L., Collatz, G. J., Kasibhatla, P. S., and Arellano Jr., A. F.: Interannual variability in global biomass burning emissions from 1997 to 2004, Atmos. Chem. Phys., 6, 3423-3441, doi:10.5194/acp-6-3423-2006, 2006.

Van der Werf, G. R., Randerson, J. T., Giglio, L., Gobron, N., and Dolman, A. J.: Climate controls on the variability of fires in the tropics and subtropics, Global Biogeochem. Cy., 22, GB3028, doi:10.1029/2007GB003122, 2008.

Wagenbach, D., Görlach, U., Moser, K., and Münnich, K. O.: Coastal Antarctic aerosol: the seasonal pattern of its chemical composition and radionuclide content, Tellus B, 40, 426-436, 1988.

Weller, R., Minikin, A., Wagenbach, D., and Dreiling, V.: Characterization of the inter-annual, seasonal, and diurnal variations of condensation particle concentrations at Neumayer, Antarctica, Atmos. Chem. Phys., 11, 13243-13257, doi:10.5194/acp11-13243-2011, 2011.

Weller, R., Minikin, A., Petzold, A., Wagenbach, D., and KönigLanglo, G.: Characterization of long-term and seasonal variations of black carbon (BC) concentrations at Neumayer, Antarctica, Atmos. Chem. Phys., 13, 1579-1590, doi:10.5194/acp-131579-2013, 2013.
Wessel, S., Aoki, S., Winkler, P., Weller, R., Herber, A., Gernandt, H., and Schrems, O.: Tropospheric ozone depletion in polar regions A comparison of observations in the Arctic and Antarctic, Tellus B, 50, 34-50, doi:10.1034/j.1600-0889.1998.00003.x, 1998.

Wolff, E. W. and Cachier, H.: Concentrations and seasonal cycle of black carbon in aerosol at a coastal Antarctic station, J. Geophys. Res., 103, 11033-11042, doi:10.1029/97JD01363, 1998.

Wolff, E. W., Fischer, H., Fundel, F., Ruth, U., Twarloh, B., Littot, G. C., Mulvaney, R., Röthlisberger, R., de Angelis, M., Boutron, C. F., Hansson, M., Jonsell, U., Hutterli, M. A., Lambert, F., Kaufmann, P., Stauffer, B., Stocker, T. F., Steffensen, J. P., Bigler, M., Siggaard-Andersen, M. L., Udisti, R., Becagli, S., Castellano, E., Severi, M., Wagenbach, D., Barbante, C., Gabrielli, P., and Gaspari, V.: Southern Ocean sea-ice extent, productivity and iron flux over the past eight glacial cycles, Nature, 440, 491-496, doi:10.1038/nature04614, 2006.

Yamanouchi, T., Wada, M., Fukatsu, T., Hayashi, M., Osada, K., Nagatani, M., Nakata, A., and Iwasaka, Y.: Airborne observation of water vapor and aerosols along Mizuho route, Antarctica, Polar Meteorol. Glaciol., 13, 22-37, 1999. 